Article

\title{
Sustainability and Tourism Marketing: A Bibliometric Analysis of Publications between 1997 and 2020 Using VOSviewer Software
}

\author{
William Quezado de F. Cavalcante ${ }^{1,2, *(1)}$, Arnaldo Coelho ${ }^{2}$ and Cristela Maia Bairrada ${ }^{2}(\mathbb{C}$ \\ 1 Federal Institute of Education, Science and Technology of Maranhão, 65075-441 São Luis, Brazil \\ 2 CeBER, Faculty of Economics, University of Coimbra, 3004-512 Coimbra, Portugal; acoelho@fe.uc.pt (A.C.); \\ cristela.bairrada@uc.pt (C.M.B.) \\ * Correspondence: william.cavalcante@ifma.edu.br
}

Citation: Cavalcante, W.Q.d.F.;

Coelho, A.; Bairrada, C.M.

Sustainability and Tourism

Marketing: A Bibliometric Analysis of Publications between 1997 and 2020 Using VOSviewer Software. Sustainability 2021, 13, 4987. https:// doi.org/10.3390/su13094987

Academic Editor: Colin Michael Hall

Received: 31 March 2021

Accepted: 26 April 2021

Published: 29 April 2021

Publisher's Note: MDPI stays neutral with regard to jurisdictional claims in published maps and institutional affiliations.

Copyright: (c) 2021 by the authors. Licensee MDPI, Basel, Switzerland. This article is an open access article distributed under the terms and conditions of the Creative Commons Attribution (CC BY) license (https:/ / creativecommons.org/licenses/by/ $4.0 /)$.

\begin{abstract}
Several studies have empirically explored the association between practices in sustainable tourism and their impact on tourism marketing. However, bibliometric studies that organize the production in this field are still scarce. The objective of this study is thus to provide a bibliometric analysis of research on sustainable practices in tourism related to marketing, identifying the state of the art, trends and other indicators, by monitoring the articles published on the Web of Science (WoS) platform. A sample of 694 materials was obtained. The data were processed and the results graphically illustrated using the VOSviewer software. The study analyzed the simultaneous occurrence of publications by year, keyword trends, cocitations, bibliographic coupling and analysis of coauthorship, countries and institutions, and indicates that the literature on tourism sustainability issues in the field of tourism marketing is growing at a quick pace; merely five papers accounted for more than 2193 citations, but there are several prolific authors. Of the 694 sources included in the review, the most important ones published $40.34 \%$ of the papers; Spain is the leading country in this topic. This research provides insight about the state of the art and identifies gaps and research opportunities in sustainability and tourism marketing.
\end{abstract}

Keywords: sustainability; sustainable tourism; tourism management; ecotourism; destination marketing; bibliometric analysis; systematic literature review

\section{Introduction}

Public awareness of sustainability and balanced economic development is increasing due to economic growth [1-3]. Natural resources are under pressure and the environment is being harmed as a result of consumption increase. Hence, challenges linked with water and air pollution, climate change, biodiversity loss and depletion of resources must be addressed [2,4]. In this context, sustainability has been highlighted as fundamental in business development, and the interest in theoretical and empirical research has grown [5].

In the tourism field, sustainability has become a critical issue for business continuity. Tourist destinations need to be cared for, and the preservation of their natural resources is fundamental, along with guaranteeing economic continuity [6-10]. Thus, environmental conservation and sustainability in tourism became relevant topics, giving rise to several new research fields [11,12], therefore contributing to a consistent development of destinations [13]. For tourist organizations, being perceived as sustainable is not just a competitive advantage, but a key factor for business survival and development $[12,14,15]$. Being perceived as sustainable can lead to positive attitudes towards organizations and effective increases in customer-company commitment and identification [2,16].

Studies regarding sustainability have captured scholars' interest, mainly in tourism research $[7,11,15,17,18]$, probably due to the need to preserve heritage and other facilities in potential tourist destinations [13]. Tourism is one of the core sectors in terms of job creation 
and economic development; therefore, balanced and sustainable growth became a global challenge [3]. Understanding the importance of sustainability in tourism is essential for the development of destination marketing strategies. Several studies have explored the association between sustainable tourist practices and their impact on destination, marketing and branding $[2,14,16,19]$. Sustainable tourism can be an alternative to economic activities that have great impacts on nature, mitigating negative effects and contributing to environment preservation [20]. In addition, when tourism incorporates nature conservation, there is a positive impact on tourists' perceptions, and on local communities' social, economic and cultural sustainability [21,22].

Nature-based tourism is increasing and is putting destinations' natural resources under stress. On the contrary, little investigation has been carried out on this matter [21]. Although there has been an apparent growing interest in the topic, with some publications on sustainability in tourism, bibliographic studies are still scarce [3,13]. Even if the preference for bibliometric studies is increasing, the sustainability field offers plenty of opportunities for this methodology [13]—namely, to identify future trends and directions. Despite the fact that attempts have been made to identify some key indicators and measures to deal with sustainable challenges, an overall approach is needed [11] in order to provide a full understanding of the problem.

Consequently, this paper seeks to provide a bibliometric approach to tourism sustainability research related to marketing and branding, identifying the state of the art in this field and, more precisely, identifying trends and other relevant indicators by surveying the articles published on Web of Science, with subsequent treatment using VOSviewer software. Based on a content analysis of recent publications, we identify gaps and opportunities of sustainability research in tourism.

\section{Literature Review}

\subsection{Sustainability and Sustainable Development in Tourism: A Theoretical Approach}

Tourism growth might not be compatible with sustainability goals [4]. An approach based on growth might not be a sustainable way of developing tourism $[4,5,16,19,23]$. The destruction of tourism by tourism itself is a growing problem which calls for new approaches and new answers. The emergence of sustainability and responsibility in the tourism field is putting individuals and organizations under pressure to manage and implement tourist activities with environmental and ethical concerns [5]. The sustainability urgence is linked to the assumed notion that nature and natural assets are limited. In the context of resources and environment, sustainability means maintaining or extending the productive use of resources and the integrity of resource sources [24-26]. This entails, among other things, that there are physical limits and other restrictions on the use of natural resources and that there are obligations towards the maintenance and improvement of nature [3,13]. Three distinct approaches to sustainability can be identified: (1) as a purely physical concept for a single resource; (2) as a physical concept for a group of resources or ecosystems; and (3) as a socio-physical-economic concept [24]. When addressed in the context of the social and economic sciences, sustainability has evolved into the concept of sustainable development. Sustainable development can be defined as the ability to meet the needs of the present without compromising the growing capacity of future generations to fulfil their own needs $[13,24]$. Thus, it represents the acknowledgment of the limitations, enforced by the current state of technology and social organization, of dealing with environmental scarce resources and the ability of the biosphere to absorb the effects of human activities [27].

Thus, sustainability means using no more than the annual increase in the resources available without reducing the physical stock [24]. This is similar to using interests earned on a savings account, but leaving the main invested principal to continue to generate interest in the future [24]. Hence, sustainability comprehends a set of concepts linked to economic, social and environmental issues, such as the green economy and the circular economy. All of these concepts are based on responsible production and consumption, 
through the efficient use of resources and the reduction in waste [3]. Most of the tourism activities leave a marked environmental footprint and require greater involvement of individuals, private companies and all the agencies for the conservation of natural resources, regional development, and protection of cultural and environmental heritage [23].

In the context of tourism, a Resource-Based View (RBV) can offer a theoretical view of the importance of resources for the competitive differentiation and sustainability of the tourist destination [28]. Thus, an RBV is important for two reasons: first, Resources are the main element of the destination. Second, resources depreciate over time, so we need to understand which resources make your destination more competitive to better manage what attracts visitors in a sustainable way [29]. In this view, an RBV approach can lead to a more sustainable strategy for the use of resources [28]. Therefore, RBV is very relevant in the context of sustainability in tourism, providing a dynamic and resource-based perspective in the analysis of tourist destinations [30].

Another important theoretical contribution to a better comprehension of sustainability in tourism is provided by the Stakeholder Theory, which has been widely used in studies in this field of investigation. A stakeholder is "any group or individual who can affect or is affected by the achievement of the organizations' objectives" [31]. When applied to tourism, the Stakeholder Theory suggests that the interests of all those who affect or may be affected by its developments should be considered [32,33]. The stakeholder theory addresses the idea that organizations and places are driven by the goal of creating value $[34,35]$. However, their vision must be holistic and go far beyond the pursuit of profitability only for investors [31], directing efforts to other interested parties, such as residents and tourists [36-38], sharing value with them [39-41].

\subsection{Perceived Sustainability in Tourism}

The development of tourism in local communities, far from mass tourism, needs to provide an experience that raises awareness of the need to preserve communities' traditions [15], their surroundings, and the practice of sustainable tourism [22,23]. Being truly committed to sustainability is imperative for destinations [42], and being perceived as sustainable by visitors is paramount [12]. Perceived sustainability is the customer's perceptions of a certain product and/or service's performance related to the environment $[14,19,43]$. The perception of sustainability in tourism is a key concept that differs from one consumer to another, as it is based on the stakeholders affective-cognitive assessment, regarding sustainability policies applied to a specific destination [19]. The signaling theory literature brings a new centrality to perceptions, as they represent symbolic benefits linking sustainability, reputation and loyalty [44-46].

Perceived sustainability comprises three dimensions: economic, socio-cultural and environmental $[14,47]$. First, the economic dimension seeks to meet the economic needs of the host population, maximizing results and minimizing costs to increase the vitality of the tourism industry [48]. More specifically, economically sustainable tourism aims at more employment and income opportunities, better infrastructure, growth and better living standards [49]. The social and cultural dimension highlights protection of local areas, social and cultural resources of communities, and the interaction between humans and the environment $[27,43]$. This dimension focuses on activities that promote opportunities for cultural exchanges and interactions between suppliers, travel agencies, residents and tourists [2,5]. Finally, the environmental dimension of perceived sustainability enables protection of environmental capital, biodiversity and raises attention to the use of renewable and nonrenewable resources [14]. This dimension also addresses the economic benefits of environmental protection in a tourist destination in order to reduce the negative influences of guests and educate and engage them as well as residents in the environment protection [48]. In this context, the success of a destination and the reinforcement of sustainable tourism is bidirectional and depends, mainly, on tourists; the tourist's decision to travel is strongly influenced by the value of natural resources they perceive; therefore, public 
authorities must be aware of and manage destination sustainability actions and practices to ensure they are relevant and coherent with the nature of the destination [48].

After three decades of discussing paths to sustainable tourism, tourism authorities continue to promote tourism growth instead of recognizing ecological and social constraints of a planet with limited resources [4]. In the academic literature, several studies have been developed, seeking to deepen the understanding of sustainability and the way it is perceived, and contributing to its conceptual development, even if further research is needed $[2,5,6,14,16,19,38,43,50]$. The innovation of the new approaches lies in the need to engage tourists in the sustainable process, in two main directions: tourist engagement in sustainable behavior during their touristic activities $[17,48,50]$; tourist sustainability perceptions, capturing their approval of the sustainability actions and practices deployed [12,16].

\subsection{Marketing and Branding of the Tourist Destination}

Since the beginning of the 1990s, there has been an increase in branding initiatives in the area of destination marketing. They can be seen in place labelling, positioning strategies and representative visual images [51-54]. When thinking about a place as a destination, it is necessary to analyze all the features related to that place: it is a geographical place and, at the same time, a metaphysical space, filled with meaning and values [55]. A place marketing literature review reveals different concepts and different definitions for destinations and brands. Two main approaches seem to prevail: urban planning; and tourism and vacation marketing [56]. Urban planning focuses on the nature of local products, their historical development, and the marketing implications of distinctive local features. Vacation marketing deals with the conceptual field of the destination brand, through the concept of brand networks, where the brand of the place performs four main functions in the communication with the guest [57]: as a communicator, a perceptual entity, a value enhancer, and as a relationship. In this context, one of the biggest challenges for destination marketers is to position their destination vis-a-via a myriad of competing locations offering similar features [51].

The interest of tourist organizations in brand positioning is supported by a marketing orientation that recognizes the existence of an unlimited range of competing destinations to choose from $[51,58,59]$. Since they are not only geographical places, but also metaphysical, with subjective and intangible features, destinations can awaken people's feelings that may be expressed through strong emotional connections, either positive or negative. Since positioning requires narrow focus, sustainability can represent a succinct and meaningful proposition [51], a strong quality of the tourist destination [14], setting it apart from competition, while guaranteeing the development and continuity of the place and the business [60].

Previous studies have related perceived sustainability to marketing variables, such as value creation, image, product/service performance and behavioral and perceptual consumer issues [14]. Perceived sustainability was also associated with satisfaction [14,43], perceived value [14], intention to revisit [48], word-of-mouth [48] and market segmentation [19]. Sustainability is increasingly understood as a key competitive advantage in the tourism industry [23], providing substantial benefits to tourist destinations. Under a sustainable approach, tourism may benefit from the actual natural assets and contribute to their maintenance and development $[8,21]$, therefore bringing prosperity to destinations and communities, and helping to preserve nature and build a better world [61,62].

\section{Methodology}

This study is based on a bibliometric review of sustainability studies, related to tourism marketing. It is suggested that systematic reviews of literature in the area of management follow three stages-namely, planning and conducting the review and reporting/disseminating the results [63]. This study adopts this methodology for the review. The bibliometric review methodology is important as it provides a categorized view of the documents published in each research area, based on objective criteria for analyzing 
and classifying publications. The use of the VOSviewer software, in turn, provides the possibility to present the data in a graphical way, through category maps.

Data were collected in September 2020 from one of the most important bibliographic databases: Web of Science. Data were collected from the WoS Core Collection database, which incorporates others subdatabases. WoS and Scopus are the most used and reliable databases [13]. However WoS "collects scientific publications with the most significant impact and is used as the main criterion in academic decision making" [64] (p. 3). Therefore, following past investigations procedures [65-67], we used WoS after crossing with Scopus and confirming it did not offer any additional relevant references.

The query for the term "Sustainability and Tourism" yielded a total of 3831 results. Through a refinement of the terms searched, we chose TS $=$ (Sustainability) AND TS $=($ Tourism OR Destination) AND TS $=$ (Marketing OR Brand), obtaining 895 results. Boolean operators were applied to filter the results: English language documents of the type article, review and early access; fixed time: 1900-2020; Indexes: SCI-EXPANDED, SSCI, ESCI. In the WoS categories, we selected hospitality leisure sport tourism, green sustainable science technology, environmental sciences, environmental studies, management, business, economics, geography, ecology, environmental engineering, interdisciplinary social sciences, biodiversity conservation, and water resources.

Bibliometric analysis was performed using bibliometric indicators, which are the mechanisms used to analyze and interpret the data collected [13]. After the application of the Boolean operators, 694 bibliographic materials were obtained, which are analyzed in the present research. The data were then processed using a similarity visualization program (VOSviewer) to graphically present some of the potential results. The study used simultaneous occurrence of publications by year, keyword trends, cocitation, bibliographic coupling and coauthor analysis between both countries and institutions. The results determined the state of development and the main trends from the point of view of influence, main journals, articles, topics, authors, institutions, and countries. Analysis and graphic representation are important, as they can help academics and professionals better understand what has been researched in the field of sustainability, with results related to tourism marketing and mapping of the main trends in the area. The quotation is produced when two documents receive a quotation from the same article. This approach is implemented by document, journal and author. Author co-occurrence of keywords measures the most common keywords used in documents. Coauthorship indicates the volume of publications for a set of variables and how they are connected with each other, and the bibliographic coupling occurs when two documents cite the same document [68]. This approach can be applied to institutions and countries.

\section{Data Analysis}

\subsection{Subsection Publications by Year}

The first article related to sustainability in tourism and marketing that was identified in Web of Science (WoS) is from 1997 and it was published in the Journal of Tourism Management with the title "Tour operators and destination sustainability" by Carey et al. [69]. This article aimed to "examine the tour operators' influence on the long-term sustainability of destinations" (p. 425). Publications on the subject became regular in 2008, when 19 articles were published on this topic. The number of publications has grown substantially ever since (shown in Figure 1).

As for annual productivity, only one article was published per year between 1997 and 2004 (0 in 2001). Four articles were published in 2005, 6 in 2006, 6 in 2007, 19 in 2008 and 12 articles in 2009. In 2010, there was an increase, with 27 articles. In 2011, 30 articles were published, 33 articles in 2012, 38 articles in 2013, 39 articles in 2014, 51 articles in 2015, 57 articles in 2016, 72 articles in 2017, 86 articles in 2018, 126 articles in 2019, and by September 2020, 82 articles. Figure 1 illustrates the annual trends in publications on this topic, generated from the sample of 694 articles. The number of publications reached a peak in 2019 with 126 published articles. It is also noteworthy that data collection was 
carried out in September 2020 and, therefore, as it is a growing topic, more papers are expected to have been published in 2020 than in 2019. After analyzing the growth in the number of articles on sustainability and tourism marketing published over the years, the analysis will be refined to disclose information allowing for a better understanding of the relevance of past research.

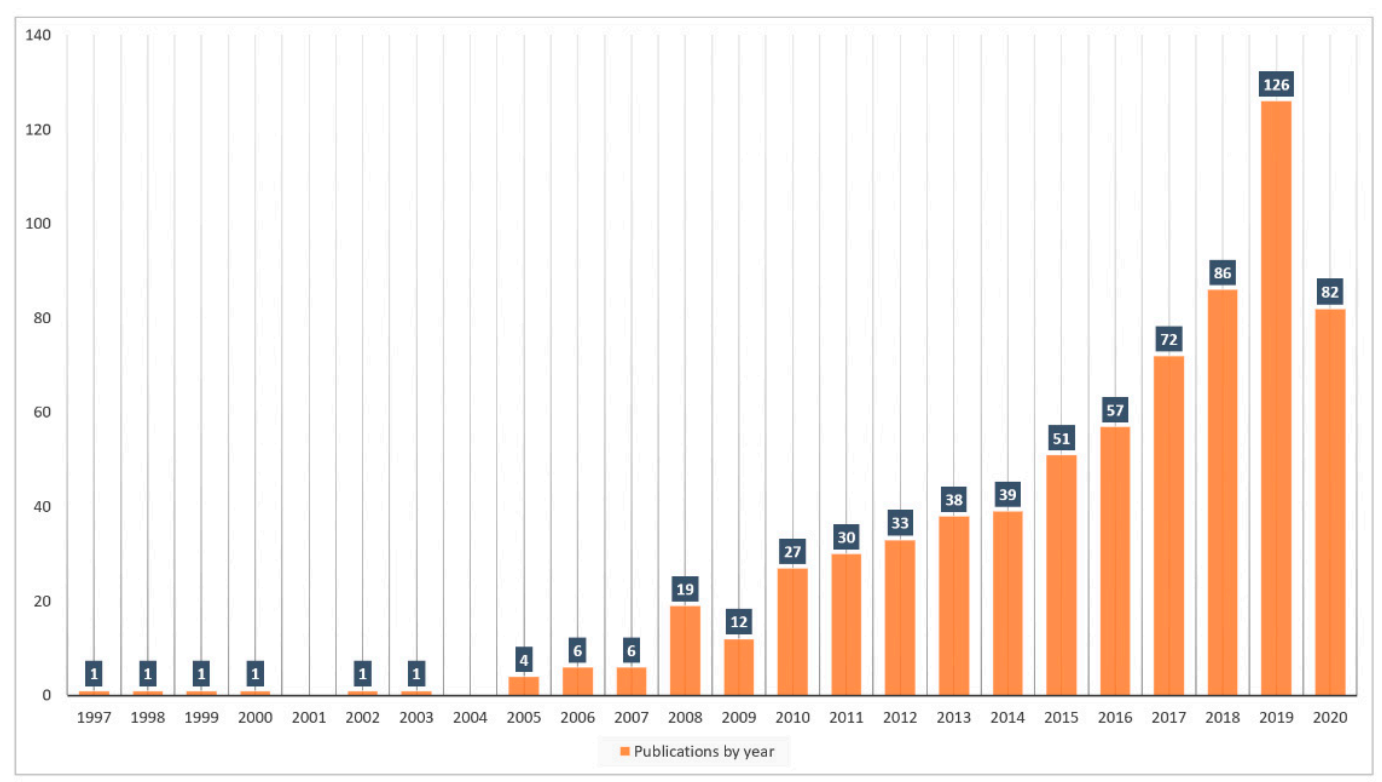

Figure 1. Publications by year (1997-2020).

The 694 articles are divided into the thirteen categories shown in Table 1. The category "Hospitality Leisure Sport Tourism" is the main category with 398 associated articles, equivalent to $57.4 \%$ of the total. The second category with most associated articles is "Green Sustainable Science Technology" with 172 articles, followed by "Environmental Sciences" with 138 articles. It is important to note that the same article can be classified under more than one category, which may impair partial and total statistics.

Table 1. Number of publications by category (1997-2020).

\begin{tabular}{ccc}
\hline Web of Science Categories & Number & \% de 694 \\
\hline Hospitality Leisure Sport Tourism & 398 & $57.349 \%$ \\
Green Sustainable Science Technology & 172 & $24.784 \%$ \\
Environmental Sciences & 138 & $19.885 \%$ \\
Environmental Studies & 131 & $18.876 \%$ \\
Management & 102 & $14.697 \%$ \\
Business & 48 & $6.916 \%$ \\
Economics & 37 & $5.331 \%$ \\
Geography & 35 & $5.043 \%$ \\
Environmental Engineering & 23 & $3.314 \%$ \\
Social Sciences Interdisciplinary & 17 & $2.450 \%$ \\
Ecology & 14 & $2.017 \%$ \\
Biodiversity Conservation & 5 & $0.720 \%$ \\
Water Resources & 5 & $0.720 \%$ \\
\hline
\end{tabular}

\subsection{Publications by Journal}

Analyzing the journals where the 694 articles were published, we note that there are 196 different journals (shown in Table 2). 
Table 2. Summary of productivity of journals (1997-2020).

\begin{tabular}{ccc}
\hline Production Volume by Journal & Journals & \% of $\mathbf{1 9 6}$ \\
\hline 1 Published Article & 102 & $52.04 \%$ \\
2 Published Articles & 27 & $13.78 \%$ \\
3 Published Articles & 20 & $10.20 \%$ \\
4 Published Articles & 14 & $7.14 \%$ \\
5 Published Articles or more & 33 & $16.84 \%$ \\
Total & 196 & $100.00 \%$ \\
\hline
\end{tabular}

Out of 196 journals, $52.04 \%$ published only one article on the researched topic, which is an indicator that these journals are not from the area of sustainability and tourism marketing; $13.78 \%$ (27 journals) published only two articles; $10.2 \%$ (20 journals) published three articles; $7.14 \%$ (14 journals) published four articles and 16.84\% (33 journals) can be considered journals of tourism marketing, as they published five or more articles (see Table 2). In addition, we can also see in Figure 2 that this research topic is very transversal and can be published in journals from different fields and with different approaches.

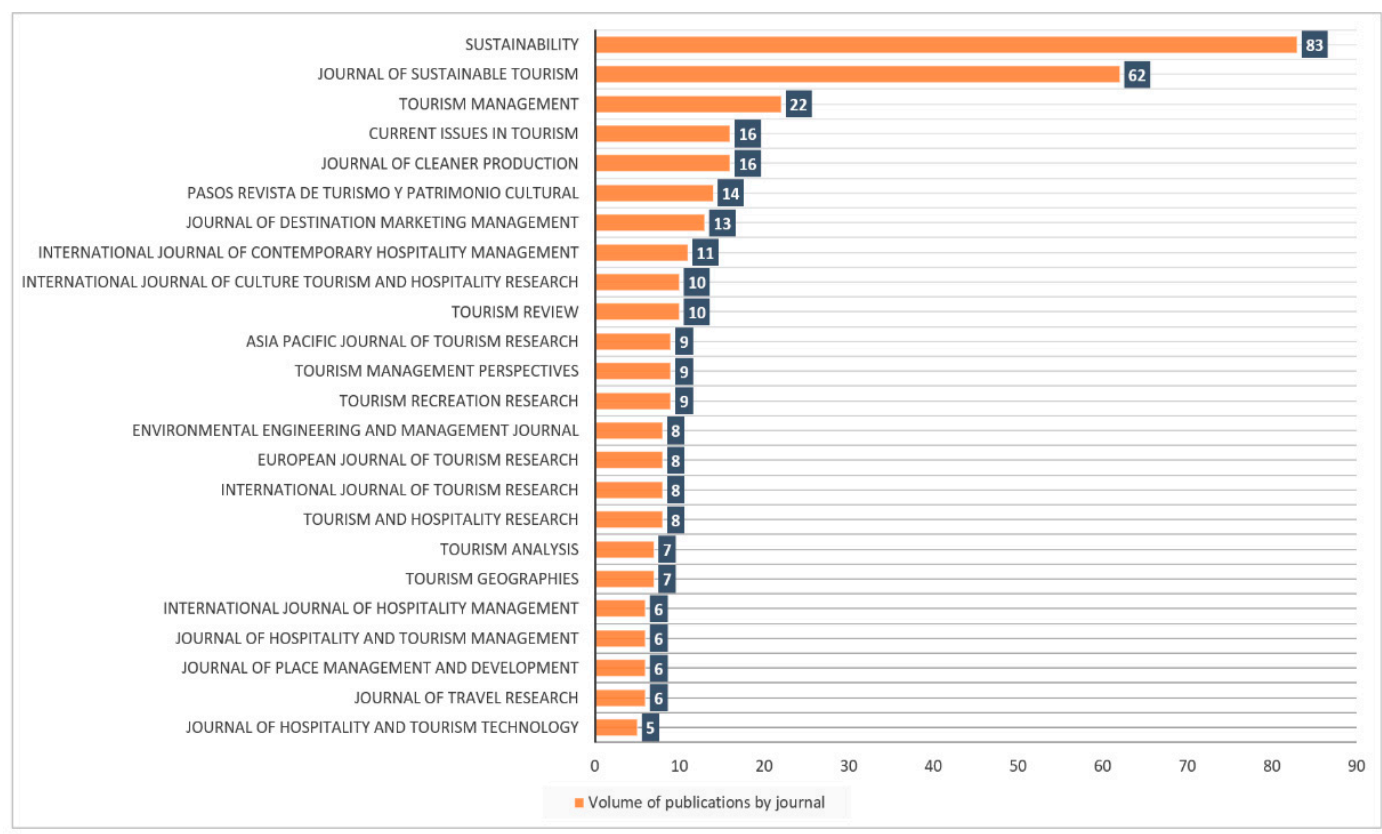

Figure 2. Publications by year (1997-2020).

As seen in Table 3, we analyzed journals with 10 or more articles published in the area, totaling 11 journals. These journals together published 280 articles, which represents $40.34 \%$ of the sample articles. It can be seen that the journal "Sustainability" is the leader in the number of published articles (83 articles), which represents $11.96 \%$ of the total sample, followed by the "Journal of Sustainable Tourism" with 8.934\% (62 articles), "Worldwide Hospitality and Tourism Themes" with 3.314\% (23 articles) and "Tourism Management" with $3.17 \%$ (22 articles).

\subsection{Keyword Analysis}

The most frequently used keywords were identified and analyzed to classify the 694 articles that are part of the sample. From this analysis, the topics arising more often in the analyzed area stand out. The map represented in Figure 3 groups the keywords into six clusters. The main keyword per cluster is satisfaction (purple cluster), sustainability (dark blue cluster), tourism (red cluster), management (green cluster), sustainable tourism (yellow cluster) and attitudes (light blue cluster). This map highlights, further, that sustainable 
tourism, attitudes and satisfaction seem to be the direction the research is taking and where new research opportunities might be arising.

Table 3. Number of publications by journal (1997-2020).

\begin{tabular}{lccc}
\hline $\mathbf{R}$ & Publication by Journal & Number & $\mathbf{\%}$ of $\mathbf{6 9 4}$ \\
\hline 1 & Sustainability & 83 & $11.960 \%$ \\
2 & Journal of Sustainable Tourism & 62 & $8.934 \%$ \\
3 & Worldwide Hospitality and Tourism Themes & 23 & $3.314 \%$ \\
4 & Tourism Management & 22 & $3.170 \%$ \\
5 & Current Issues in Tourism & 16 & $2.305 \%$ \\
6 & Journal of Cleaner Production & 16 & $2.305 \%$ \\
7 & Pasos Revista de Turismo y Patrimonio Cultural & 14 & $2.017 \%$ \\
8 & Journal of Destination Marketing Management & 13 & $1.873 \%$ \\
9 & International Journal of Contemporary & 11 & $1.585 \%$ \\
10 & Hospitality Management & & \\
11 & International Journal of Culture Tourism and & 10 & $1.441 \%$ \\
\hline
\end{tabular}

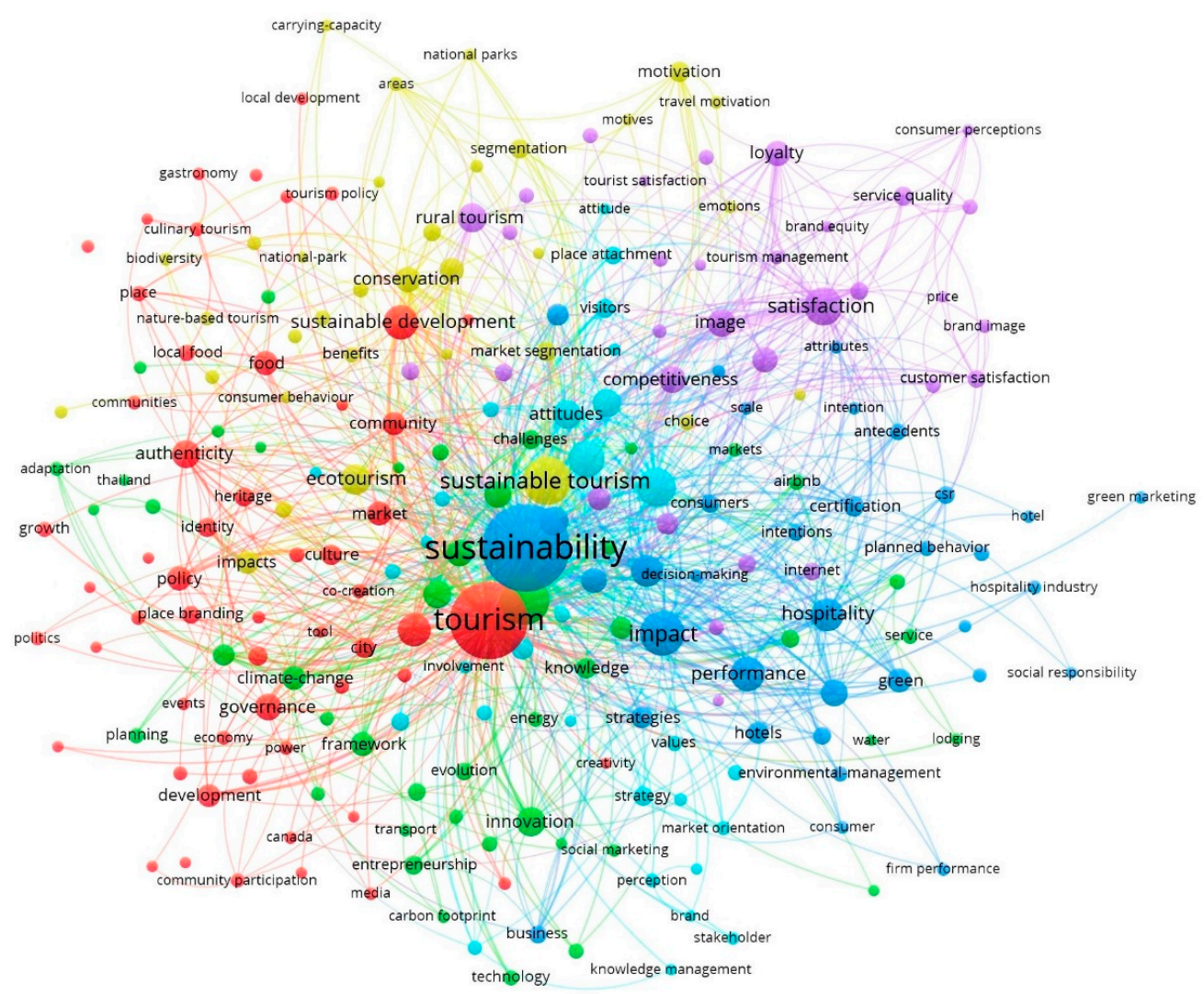

Figure 3. Keyword trends (1997-2020).

From the 694 articles, 3271 keywords were identified. Of these, 2509 words appeared only once, which means a $76.7 \%$ prevalence. Another 233 keywords appeared more than five times, equivalent to $7.12 \%$; 38 keywords were identified in at least 20 articlesi.e., $1.16 \%$; and only seven words occurred more than 50 times, equivalent to $0.21 \%$. The keywords "sustainability", "tourism", "management", "impact", "satisfaction", "model" and "sustainable tourism" appeared more than 50 times. The keyword "sustainability" has an occurrence in 264 articles, being the word that is used most often used to summarize 
the main subject of the analyzed articles, followed by "tourism" with 207 occurrences and "management" with 86 occurrences.

\subsection{Geographical Analysis of Publications}

Analyzing the authors' country of affiliation, it is possible to notice that this research topic is global, since the 694 articles that are part of the sample are distributed across 90 countries. This means that, at least, one article has been published in each of these countries.

Table 4 lists the 15 countries that have produced the most academic papers in the area of research; together, they account for $86.88 \%$ of all published articles. According to the data, Spain is the country with the highest number of publications, totaling 107 articles, followed by the United States of America with 90 articles, and Australia with 66 articles. Brazil is in 14th place in publications, just behind New Zealand and ahead of Sweden.

Table 4. Number of publications in coauthorship by country (1997-2020).

\begin{tabular}{cccc}
\hline $\mathbf{R}$ & Coauthorship By Countries & Number & \% of $\mathbf{6 9 4}$ \\
\hline 1 & Spain & 107 & $15.418 \%$ \\
2 & United States of America & 90 & $12.968 \%$ \\
3 & Australia & 66 & $9.510 \%$ \\
4 & England & 62 & $8.934 \%$ \\
5 & Italy & 46 & $6.628 \%$ \\
6 & China & 44 & $6.340 \%$ \\
7 & Canada & 33 & $4.755 \%$ \\
8 & Portugal & 26 & $3.746 \%$ \\
9 & South Africa & 24 & $3.458 \%$ \\
10 & Germany & 20 & $2.882 \%$ \\
11 & Taiwan & 19 & $2.738 \%$ \\
13 & Mexico & 17 & $2.450 \%$ \\
14 & New Zealand & 17 & $2.450 \%$ \\
\end{tabular}

Figure 4 shows the country coauthorship map that was drawn from the sample of 694 articles. It is possible to see that the cluster of countries Spain, the United States of America and Australia are in evidence. This happens as these three countries together account for $37.9 \%$ of the publications.

The lines connecting the points shown on the map indicate the coauthorship between countries and the distance between the cluster indicates the strength between them and how much these countries publish in coauthorship. This gives a good idea of the strength of cooperative relationships in sustainability and tourism research between different countries.

\subsection{Analysis of Publications by Organization}

The top five universities responsible for the publications of the 694 articles are Griffith University, State University System of Florida, University of Queensland, University of Malaga and University of Central Florida.

However, unlike what happens in journals or countries of publication, when it comes to the volume of papers published by organization, it is clear that the occurrences are quite fragmented. There are not one (nor two, nor three) universities responsible for most publications. Griffith University ranks first tied with the State University System of Florida, with 15 publications, equivalent to $2.161 \%$ of the 694 articles. Table 5 lists the 10 organizations that have produced the most academic papers in the area of research. 


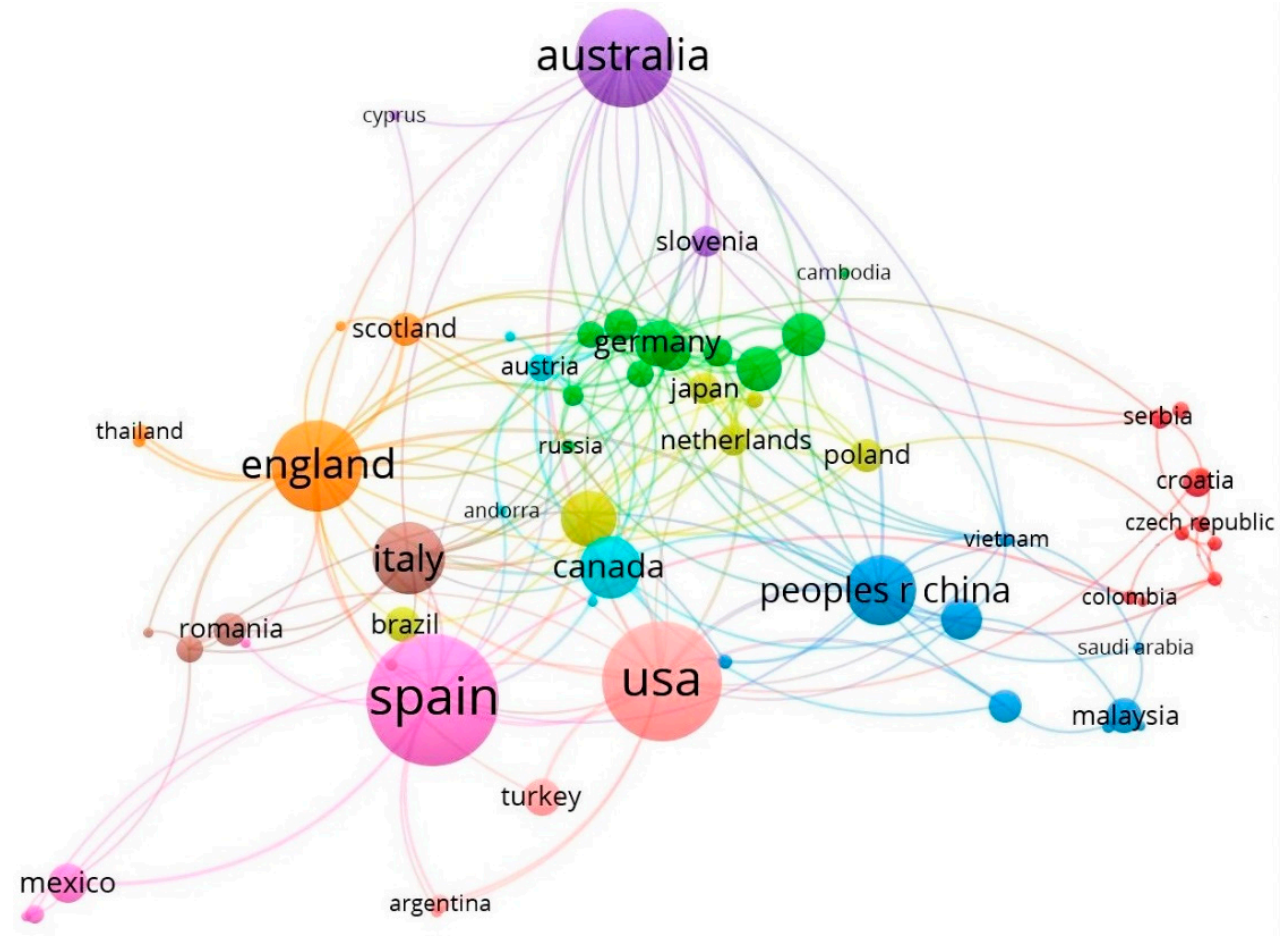

Figure 4. Coauthorship by country.

Table 5. Publications by organization.

\begin{tabular}{cccc}
\hline $\mathbf{R}$ & Organization & Number & $\mathbf{\%}$ of $\mathbf{6 9 4}$ \\
\hline 1 & Griffith University & 15 & $2.161 \%$ \\
2 & State University System of Florida & 15 & $2.161 \%$ \\
3 & University of Queensland & 12 & $1.729 \%$ \\
4 & University of Malaga & 11 & $1.585 \%$ \\
5 & University of Central Florida & 11 & $1.585 \%$ \\
6 & Hong Kong Polytechnic University & 10 & $1.441 \%$ \\
7 & University of Ljubljana & 10 & $1.441 \%$ \\
8 & Leeds Beckett University & 9 & $1.297 \%$ \\
9 & University of Aveiro & 9 & $1.297 \%$ \\
10 & University of Surrey & 9 & $1.297 \%$ \\
\hline
\end{tabular}

The map generated by the VOSviewer software (Figure 5) shows the main universities that published articles on this topic and the cooperation between the institutions. The map in question was generated from the sample of 694 articles that are part of this research.

Analyzing Figure 5, it is possible to identify the organizations responsible for the publications and the connections between them. In the results represented by Figure 5, generated by the Web of Science, we see Griffith University standing out, as well as the State University System of Florida, University of Queensland, University of Malaga, among others.

\subsection{Analysis of Citations}

The analysis of article citations is the most widely used method of assaying the impact of authors, journals and articles, since it identifies the key papers in the research area [68]. Table 6 analyzes the structure of citations in the relevant area of research. It is possible to see which articles are most cited in this area, with "Marketing the competitive destination of the future" being the reference publication, which has a total of 1145 citations. 


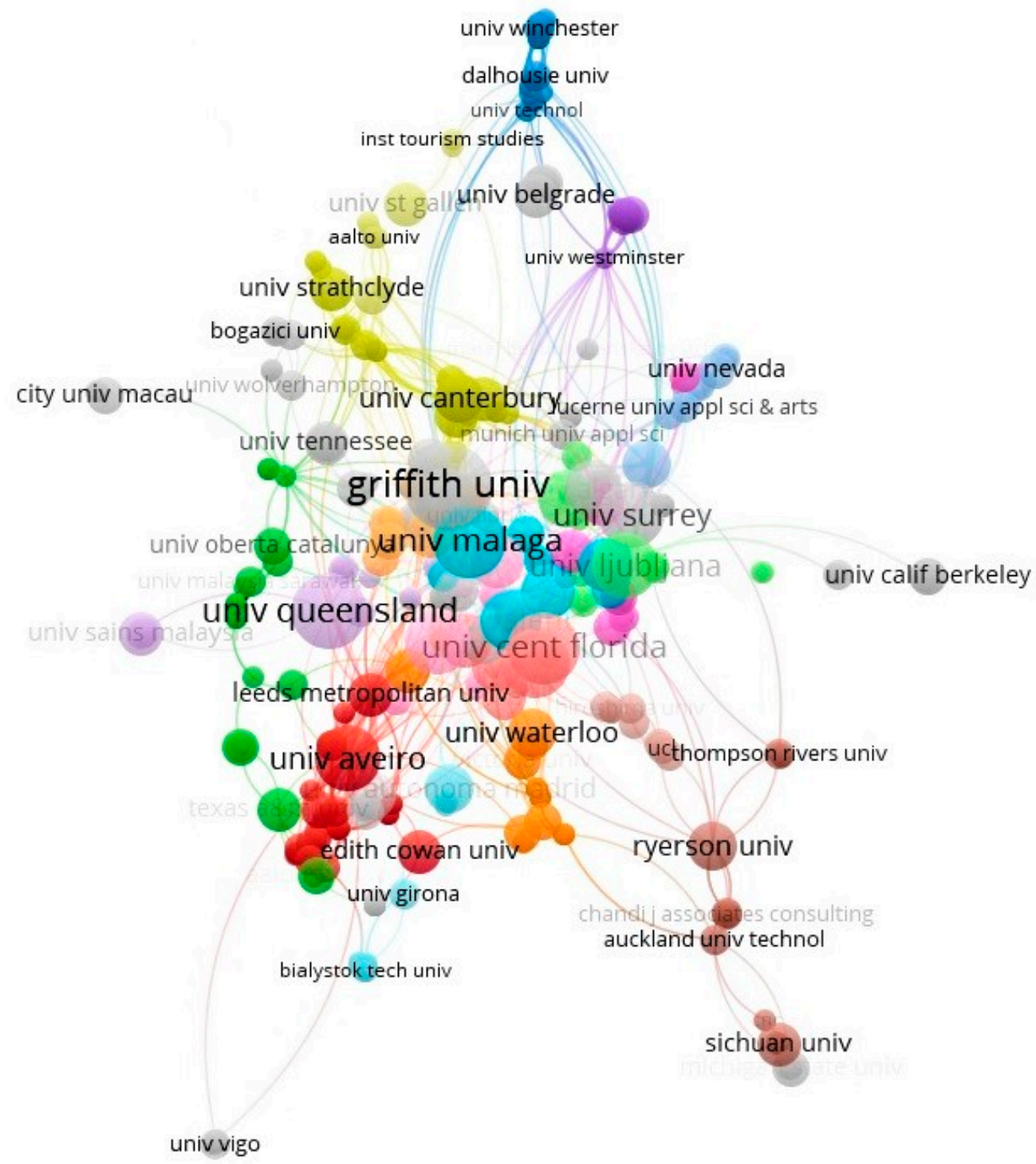

Figure 5. Publication volume-relevance of organizations.

Understanding the most cited articles, in terms of both historical average and annual average, can help researchers to identify the seminal material that can be used as a reference to support their studies, so that there is, in advance, a clear starting point.

Analyzing Figure 6, it is possible to identify the author citation network.

The citation is produced when two documents refer to the same document. This approach is implemented for documents, journals and authors [68] and serves to demonstrate the relevance of a document for a thematic area. The Spanish author Xavier Font appears in the red cluster as one of the authors mentioned most often, in addition to other names, such as Larry Dwyer.

\subsection{Analysis by Author}

The last analysis addresses production and publication by author. Table 7 identifies the most prolific author. Spanish professor Xavier Font from the University of Surrey has nine of the 694 publications, followed by the Australian author Larry Dwyer, professor at the University of Technology Sidney. 
Table 6. Citations by articles.

\begin{tabular}{|c|c|c|c|c|c|}
\hline Title & Authors & Journal & Year & Citation & $\begin{array}{l}\text { Annual } \\
\text { Average }\end{array}$ \\
\hline Marketing the competitive destination of the future & Buhalis, D. & Tourism Management & 2000 & 1145 & 54.52 \\
\hline Sustainable tourism: research and reality & Buckley, R. & Annals of Tourism Research & 2012 & 357 & 39.67 \\
\hline $\begin{array}{l}\text { Determinants of tourism success for DMOs \& } \\
\text { destinations: An empirical examination of } \\
\text { stakeholders' perspectives }\end{array}$ & Bornhorst, T.; Ritchie, J. R. B.; Sheehan, L. & Tourism Management & 2010 & 289 & 26.27 \\
\hline $\begin{array}{l}\text { The role of ecotourism in conservation: panacea or } \\
\text { Pandora's box? }\end{array}$ & Kruger, $\mathrm{O}$. & $\begin{array}{l}\text { Biodiversity and } \\
\text { Conservation }\end{array}$ & 2005 & 222 & 13.88 \\
\hline $\begin{array}{l}\text { Playing with risk? Participant perceptions of risk } \\
\text { and management implications in adventure tourism }\end{array}$ & Cater, C. I. & Tourism Management & 2006 & 180 & 12 \\
\hline $\begin{array}{l}\text { Corporate social responsibility: The } \\
\text { disclosure-performance gap }\end{array}$ & $\begin{array}{l}\text { Font, X.; Walmsley, A.; Cogotti, S.; } \\
\text { McCombes, L.; Haeusler, N. }\end{array}$ & Tourism Management & 2012 & 131 & 14.56 \\
\hline Current issue in tourism: The authentic tourist & Yeoman, I.; Brass, D; McMahon-Beattie, U. & Tourism Management & 2007 & 113 & 8.07 \\
\hline $\begin{array}{l}\text { From contents to processes: Versus a dynamic } \\
\text { destination management model (DDMM) }\end{array}$ & Sainaghi, R. & Tourism Management & 2006 & 111 & 7.4 \\
\hline $\begin{array}{l}\text { Co-creation and higher order customer engagement } \\
\text { in hospitality and tourism services. A critical review }\end{array}$ & $\begin{array}{l}\text { Chathoth, P. K.; Ungson, G. R.; Harrington, } \\
\text { R. J.; Chan, E. S. W. }\end{array}$ & $\begin{array}{l}\text { Int. Journal of Contemporary } \\
\text { Hospitality Management }\end{array}$ & 2016 & 104 & 20.8 \\
\hline
\end{tabular}




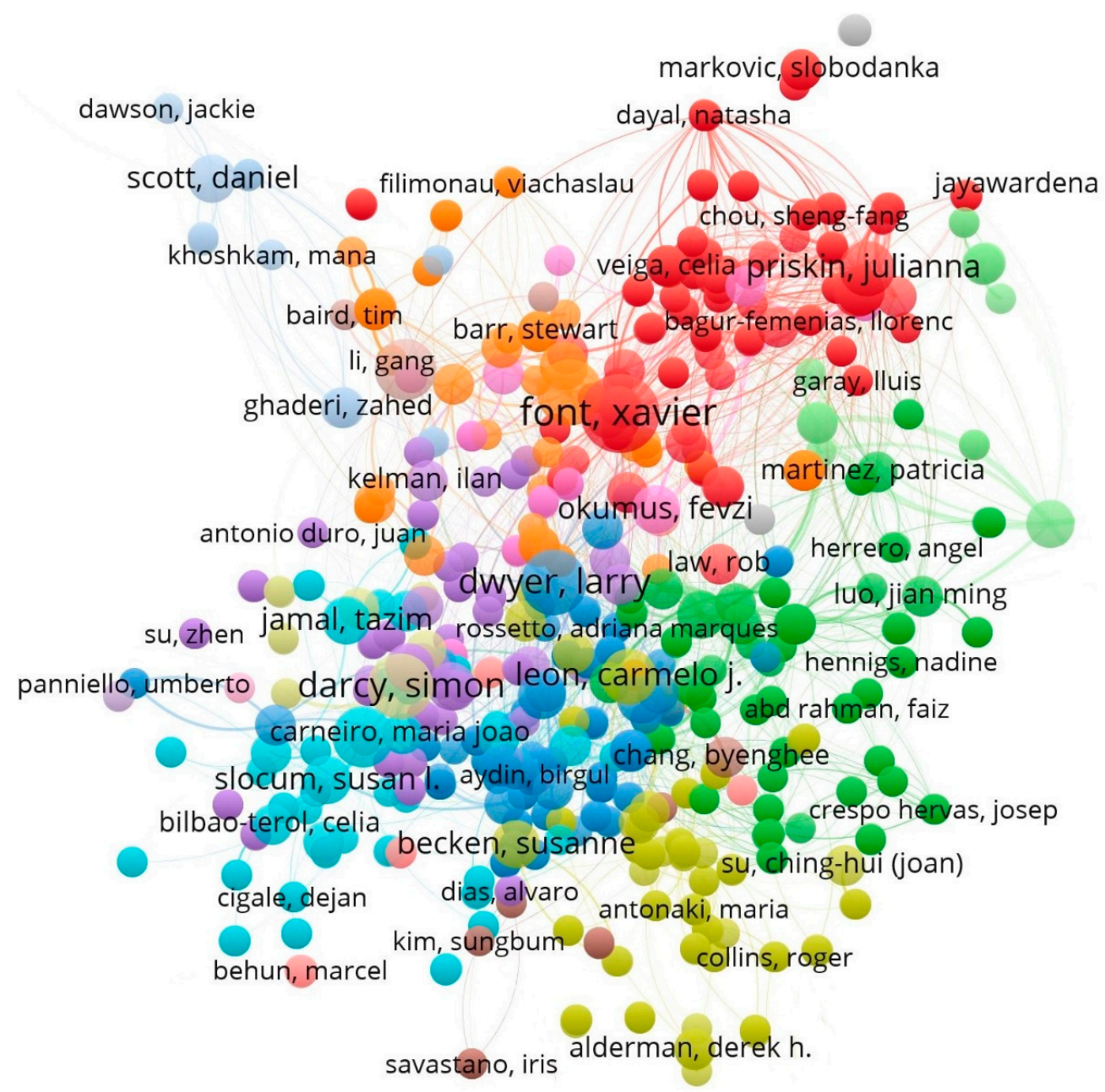

Figure 6. Author citation network.

Table 7. Publications by author.

\begin{tabular}{cccc}
\hline $\mathbf{R}$ & Authors & Number & \% de 694 \\
\hline 1 & Font, X. & 9 & $1.297 \%$ \\
2 & Dwyer, L. & 6 & $0.865 \%$ \\
3 & Hall, C.M. & 6 & $0.865 \%$ \\
4 & Dolnicar, S. & 5 & $0.720 \%$ \\
5 & Kastenholz, E. & 5 & $0.720 \%$ \\
6 & Darcy, S. & 4 & $0.576 \%$ \\
7 & Leon, CJ. & 4 & $0.576 \%$ \\
8 & Priskin, J. & 4 & $0.576 \%$ \\
9 & Saayman, M. & 4 & $0.576 \%$ \\
10 & Hales, R. & 3 & $0.432 \%$ \\
\hline
\end{tabular}

Bibliographic coupling occurs when two documents cite the same document [68], which can demonstrate the strength of a specific publication in relation to a set of other publications. This approach can be applied to papers, journals, authors, institutions and countries. Through the analysis of the bibliographic coupling of authors, it is possible to see which articles and authors are correlated, through multiple citations.

Figure 7 represents the bibliographic coupling of authors and allows us to observe and measure the intensity of the connection between them. The map reveals four well-defined clusters and the lines draw concomitant citations between the authors. 


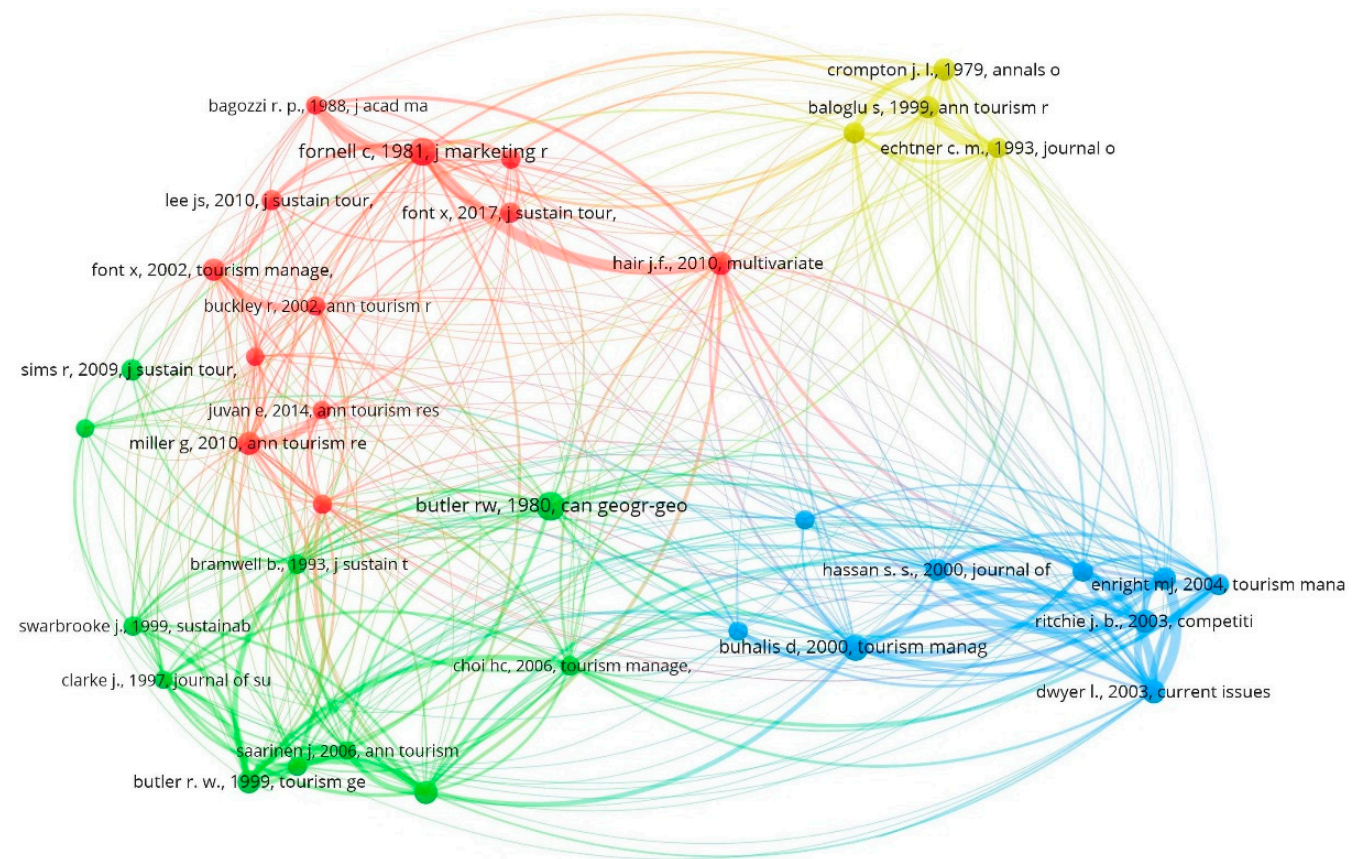

Figure 7. Bibliographic coupling of authors.

\subsection{Analysis of Research Opportunities}

The aim of this research, in addition to providing an overview of the research and directions in the investigation on sustainability in tourism, is to identify the main investigation opportunities in this field. Consequently, this section aims to analyze and propose, based on content analysis, the investigation trends and directions in this field.

The 25 papers listed in Table 8 were chosen from the analysis of 70 of the most recent and relevant articles suggested by the Web of Science. They were published in the last 5 years and were considered the most cited and relevant.

Table 8. Investigation opportunities in sustainability and tourism marketing.

\begin{tabular}{|c|c|c|c|}
\hline $\mathbf{N}$ & Opportunities & Description & Suggested Articles \\
\hline 1 & $\begin{array}{c}\text { Perceived } \\
\text { Sustainability and } \\
\text { Tourist Behavior }\end{array}$ & $\begin{array}{l}\text { The ultimate research in } \\
\text { this area focuses on } \\
\text { analyzing sustainability } \\
\text { from the guest point of } \\
\text { view, analyzing the impact } \\
\text { from variables arising from } \\
\text { marketing research. }\end{array}$ & {$[14,70-74]$} \\
\hline 2 & $\begin{array}{l}\text { Destination and Place } \\
\text { Branding }\end{array}$ & $\begin{array}{l}\text { This line of research } \\
\text { encompasses studies on } \\
\text { place branding related to } \\
\text { the economic, } \\
\text { socio-cultural and } \\
\text { environmental } \\
\text { sustainability of places } \\
\text { (place, city, country). }\end{array}$ & [75-77] \\
\hline
\end{tabular}


Table 8. Cont.

\begin{tabular}{|c|c|c|c|}
\hline $\mathbf{N}$ & Opportunities & Description & Suggested Articles \\
\hline 3 & $\begin{array}{l}\text { Destination } \\
\text { Management }\end{array}$ & $\begin{array}{l}\text { This line of research seeks } \\
\text { to investigate sustainable } \\
\text { development strategies, as } \\
\text { well as their impact on } \\
\text { destination and business } \\
\text { performance. Several } \\
\text { contexts of sustainability } \\
\text { and marketing in tourism } \\
\text { have been studied, such as } \\
\text { hotels, heritage } \\
\text { management, gastronomy, } \\
\text { parks and tourism } \\
\text { operators. }\end{array}$ & [78-82] \\
\hline 4 & $\begin{array}{c}\text { Ecotourism and Rural } \\
\text { Tourism }\end{array}$ & $\begin{array}{l}\text { Research in this area seeks } \\
\text { to analyze sustainability in } \\
\text { ecotourism and rural } \\
\text { tourism destinations and } \\
\text { businesses. Additionally, } \\
\text { they seek to understand the } \\
\text { relationship between } \\
\text { nature tourism and } \\
\text { marketing variables, such } \\
\text { as experience, destination } \\
\text { image and guest } \\
\text { satisfaction. }\end{array}$ & [83-89] \\
\hline 5 & $\begin{array}{l}\text { Maritime and } \\
\text { Island Tourism }\end{array}$ & $\begin{array}{l}\text { Maritime and island } \\
\text { tourism are an economic } \\
\text { catalyst for coastal } \\
\text { destinations. Studies in this } \\
\text { area aim to understand } \\
\text { how this sector relates to } \\
\text { the pillars of sustainability } \\
\text { and marketing variables. }\end{array}$ & [90-93] \\
\hline
\end{tabular}

The 25 selected articles were divided into five research areas using content analysis: "Perceived Sustainability and Tourist Behavior", "Destination and Place Branding", "Destination Management", "Ecotourism and Rural Tourism" and "Maritime and Island Tourism". The objective is to capture the gaps and objectives they intend to fulfill.

The five areas identified in Table 8 provide important clues about research opportunities that are evidenced and growing, representing potential fields and research contexts to be developed, as observed in the researched literature. The relationship to marketing variables and customer attitudes, as well as new investigation contexts such as ecotourism and rural tourism, or specific destinations such as maritime destinations, are particularly popular and offer new research prospects.

\section{Discussion}

The present research helps to understand the state of the art of the research in the areas of sustainability and tourism marketing. It helps to identify countries and institutions that publish the most, journals specialized in the sustainability area, especially related to tourism and marketing, and the trends in the covered subjects based on keywords, and the relevance of publications from the cocitation networks. Accordingly, it is essential for the identification of research gaps and possible future investigation trends in this area of knowledge.

This study provides an analysis of the leading journals, authors, institutions and keywords, showing that: (a) the literature on tourism sustainability in the field of tourism 
marketing is significantly growing; (b) five papers alone accounted for more than 2193 citations, and there are several prolific authors that make up a significant part of the research; (c) of the 694 sources included in this review, the main sources have published $40.34 \%$ of the papers; (d) in terms of documents and citations, Spain is the leading country in this topic; (e) according to keyword trend network analysis, sustainability is becoming a strategic approach for companies and tourist destinations. Finally, this subfield in tourism literature presents considerable potential and is expected to continue this significant growth in the coming years.

The results achieved indicate a clear trend, due to the growing focus on sustainability [8,9,94-96]. People are more concerned about the consequences of their own actions and of the products and services they consume. People wish to understand the direct impact of individual and family behaviors on nature and society [17,97]. Therefore, since consumers are more aware of social and environmental problems, there is a change in consumer behavior that leads to a greater adherence to prosocial and proenvironmental actions [42]. Therefore, the study of sustainability can help businesses last over time and cause less collateral damage. At the same time, it provides arguments to rethink mass tourism, seeking to reduce the impacts that this economic activity generates on environment and communities, by bringing it closer to customers. There is no doubt that tourism has the potential to generate jobs and income and to foster the development of places when both approaches are integrated $[23,98]$. However, it is important to know what type of tourism and what are the benefits/losses it brings to set clear and sustainable tourism strategies and develop sustainable tourist products and services [99].

Perceived sustainability, with social-economic, environmental and cultural dimensions, can be qualifiers that filter the type of tourism that is practiced, and can help to generate consumer awareness of how tourist products and services are consumed. They can also help to improve the instruments of public control over organizations and public policies to increase the adoption of sustainable practices both on the supply and demand sides [10]. In this process of developing sustainable practices, it is important to include all stakeholders involved, both guests and local residents, in addition to public agents and private service providers, as recommended by several studies [2,100].

The research by Iniesta-Bonillo et al. [14] and Sánchez-Fernández et al. [19] bring relevant contributions to the study of sustainability since they developed metrics for measuring sustainability actions, based on consumer perceptions. Customers, as well as other stakeholders, became important actors in the sustainability tourism chain. The development of tourism offers may, in fact, generate and benefit from a better sharing of the value they can create [101], bringing more stakeholders to this process. Therefore, tourists may be a critical element, a part of a virtuous cycle that starts from the existence of natural resources to their use and enjoyment, and consequent maintenance and preservation [102]. Sustainability may contribute to more balanced and long-lasting tourist benefits [73], to include and benefit more stakeholders in the process, and to bring all stakeholders together to enjoy the planet's resources and build a better world.

\section{Conclusions}

The present study contributes to the existing research by providing information on the state of the art and identifying the trends, gaps and research opportunities through the selection and content analysis of the most recent and relevant articles published in this research field. It has evidenced the importance of searching for a metric of sustainability performance by highlighting the importance and the role of perceptions, mainly customer perceptions, and demonstrating the centrality of the tourist in the adoption of sustainable actions. The perceived sustainability of the guest's experience, taking into account brand personality and the value of a tourist destination, is still under-researched. Therefore, the perceived sustainability concept can also be adapted to specific sectors of tourism, such as hotels, parks and tourist equipment. 
At the same time, the role of stakeholders in sustainability research was also identified, seeking to capture the different points of view and the respective involvement, and their relationship with sustainability issues. Publications that focus on the role of local actors have been growing in recent years and show another side to this field of research, where the local community plays a fundamental part that largely exceeds the isolated and unilateral actions of the government.

Other contributions of the present research can be listed. First, the identification of progress and development of the terms used in this research field. First "Sustainability" and then "sustainable development" are the keywords most used to refer to studies on sustainability in the organizational context. Following the strong growth in publications since 2010, new terms are incorporated, such as "perceived sustainability" and its dimensions.

A second contribution is based on understanding the rising interest in the study of sustainability, with a focus on tourism and its impacts on the management of the tourist destination's brand. In the last ten years, the volume of publications has grown 10.5 times, from 12 articles in 2009 to 126 articles in 2019, proving the growing trend in this field of research. The clusters of keywords observed through VOSviewer suggest an increase, year after year, in the research linking sustainability to consumer behavior variables, such as satisfaction, perceived image, experience, loyalty, behavioral intentions, among others. Such growing interest points precisely to the potential directions of future research and clearly identifies the impacts of sustainability on marketing strategies and outcomes.

A third contribution is the demonstration in categories and origin of related research. Among all categories, "Hospitality Leisure Sport Tourism" is the main one, with 398 associated articles, equivalent to $57.34 \%$ of the 694 articles, which shows the great predominance of publications in specialized tourism journals. The research focuses on about 15 countries that account, altogether, for $86.88 \%$ of the published articles, led by Spain with $15.41 \%$ of the publications.

Fourthly, the paper contributes to the identification of the journals that publish most of the research under the selected parameters. Sustainability features at the top of the ranking with 83 articles, accounting for $11.96 \%$ of the publications. The Journal of Sustainable Tourism appears in second place with 62 articles, accounting for $8.93 \%$ of the published total.

Finally, this investigation provides a content analysis of the most recent and relevant articles, exploring the areas and topics under investigation that seem to be more popular, and the directions investigation seems to be taking. This contribution may give precious clues to those who are investigating or intend to enter in this field of investigation. Future research may seek to identify the different views on the tourist destination and its sustainability. Comparative studies in the field of tourism marketing represent a trend as well. Different contexts, specific destinations and the central role of customers and their perceptions seem to be the most promising issues in this field.

For future research, it is also suggested that sustainability variables can be addressed in specific bibliometric research, analyzing their relationship with target marketing variables in the academic literature. Another suggestion for future bibliometric analyses may be to address a possible decrease in the production of academic research in the field of tourism in 2020 and 2021, against the backdrop of the pandemic of COVID-19, which restricted movement of people at the local and global levels, causing a consequent decrease in tourist activity.

As a limitation, the results obtained in the year 2020 are until the month of September, when the data collection was carried out. Future research may cover the whole year in order to provide a complete overview of scientific production in the year 2020. Bibliometric analysis relies on technical decisions such as choosing language and investigation fields, which may exclude relevant papers of the analysis. Another limitation is that, although other databases have been consulted, it was decided to use Web of Science exclusively. A multisource method comparing different databases might give a broad overview of the investigation in this field and a better comprehension of the main differences and implica- 
tions of using different databases. The inclusion of additional keywords, such as corporate social responsibility, which presents a significant complementarity with sustainability, sometimes even overlapping, would bring a better description of the full picture [3]. At the same time a bibliometric analysis has limited capacity to provide an analysis of the contexts and motivations behind citation behavior. Additionally, even if only the highest quality papers were considered, other works such as conferences papers, book chapters or dissertations may give precious clues about future investigations trends. A bibliometric approach provides an analysis that is eminently descriptive and may lack some content analysis to increase explanation capacity and provide a deeper analysis of the results and implications.

Author Contributions: W.Q.d.F.C., A.C., C.M.B. designed the research. The data were collected by W.Q.d.F.C. Analysis of data was performed by W.Q.d.F.C., A.C. and C.M.B. Finally, the paper was written by W.Q.d.F.C., A.C. and C.M.B. All authors have read and agreed to the published version of the manuscript.

Funding: This work has been funded by national funds through FCT—Fundação para a Ciência e a Tecnologia, I.P., Project UIDB/05037/2020.

Institutional Review Board Statement: Not applicable.

Informed Consent Statement: Not applicable.

Data Availability Statement: Web of Science (WoS).

Acknowledgments: Foundation for Research Support and Scientific and Technological Development of Maranhão-FAPEMA, SECTI, State Government of Maranhão.

Conflicts of Interest: The authors declare no conflict of interest.

\section{References}

1. Hockerts, K. A cognitive perspective on the business case for corporate sustainability. Bus. Strateg. Environ. 2015, 24, 102-122. [CrossRef]

2. Lee, Y.C. Communicating sustainable development: Effects of stakeholder-centric perceived sustainability. Corp. Soc. Responsib. Environ. Manag. 2020, 27, 1540-1551. [CrossRef]

3. Niñerola, A.; Sánchez-Rebull, M.V.; Hernández-Lara, A.B. Tourism research on sustainability: A bibliometric analysis. Sustainability 2019, 11, 1377. [CrossRef]

4. Higgins-Desbiolles, F. Sustainable tourism: Sustaining tourism or something more? Tour. Manag. Perspect. 2018, 25, 157-160. [CrossRef]

5. Mathew, P.V.; Sreejesh, S. Impact of responsible tourism on destination sustainability and quality of life of community in tourism destinations. J. Hosp. Tour. Manag. 2017, 31, 83-89. [CrossRef]

6. Cottrell, S.P.; Vaske, J.J.; Roemer, J.M. Resident satisfaction with sustainable tourism: The case of Frankenwald Nature Park, Germany. Tour. Manag. Perspect. 2013, 8, 42-48. [CrossRef]

7. Hall, C.M. Constructing sustainable tourism development: The 2030 agenda and the managerial ecology of sustainable tourism. J. Sustain. Tour. 2019, 27, 1044-1060. [CrossRef]

8. Hanqin, Q.; Fan, D.X.F.; Lyu, J.; Lin, P.M.C.; Jenkins, C.L. Analyzing the Economic Sustainability of Tourism Development: Evidence from Hong Kong. J. Hosp. Tour. Res. 2019, 43, 226-248.

9. Elmo, G.C.; Arcese, G.; Valeri, M.; Poponi, S.; Pacchera, F. Sustainability in Tourism as an Innovation Driver: An Analysis of Family Business Reality. Sustainability 2020, 12, 6149. [CrossRef]

10. Pohlmann, C.R.; Scavarda, A.J.; Alves, M.B.; Korzenowski, A.L. The role of the focal company in sustainable development goals: A Brazilian food poultry supply chain case study. J. Clean Prod. 2020, 245, 118798. [CrossRef]

11. Rasoolimanesh, S.M.; Ramakrishna, S.; Hall, C.M.; Esfandiar, K.; Seyfi, S. A systematic scoping review of sustainable tourism indicators in relation to the sustainable development goals. J. Sustain. Tour. 2020, 1-21. [CrossRef]

12. Grilli, G.; Tyllianakis, E.; Luisetti, T.; Ferrini, S.; Turner, R.K. Prospective tourist preferences for sustainable tourism development in Small Island Developing States. Tour Manag. 2021, 82, 104178. [CrossRef]

13. Garrigos-Simon, F.J.; Narangajavana-Kaosiri, Y.; Lengua-Lengua, I. Tourism and sustainability: A bibliometric and visualization analysis. Sustainability 2018, 10, 1976. [CrossRef]

14. Iniesta-Bonillo, M.A.; Sánchez-Fernández, R.; Jiménez-Castillo, D. Sustainability, value, and satisfaction: Model testing and cross-validation in tourist destinations. J. Bus. Res. 2016, 69, 5002-5007. [CrossRef]

15. Breiby, M.A.; Duedahl, E.; Øian, H.; Ericsson, B. Exploring sustainable experiences in tourism. Scand J. Hosp. Tour. 2020, 20, 335-351. [CrossRef] 
16. Leung, Y.W.; Rosenthal, S. Explicating perceived sustainability-related climate: A situational motivator of pro-environmental behavior. Sustainability 2019, 11, 231. [CrossRef]

17. Testa, R.; Galati, A.; Schifani, G.; Di Trapani, A.M.; Migliore, G. Culinary Tourism Experiences in Agri-Tourism Destinations and Sustainable Consumption-Understanding Italian Tourists' Motivations. Sustainability 2019, 11, 4588. [CrossRef]

18. He, L.; Zha, J.; Loo, H.A. How to improve tourism energy efficiency to achieve sustainable tourism: Evidence from China. Curr. Issues Tour. 2020, 23, 1-16. [CrossRef]

19. Sánchez-Fernández, R.; Iniesta-Bonillo, M.Á.; Cervera-Taulet, A. Exploring the concept of perceived sustainability at tourist destinations: A market segmentation approach. J. Travel. Tour. Mark. 2019, 36, 176-190. [CrossRef]

20. Siakwah, P.; Musavengane, R.; Leonard, L. Tourism Governance and Attainment of the Sustainable Development Goals in Africa. Tour. Plan. Dev. 2020, 17, 355-383. [CrossRef]

21. Winter, P.L.; Selin, S.; Cerveny, L.; Bricker, K. Outdoor Recreation, Nature-Based Tourism, and Sustainability. Sustainability 2019, 12, 81. [CrossRef]

22. Marrosu, G.M.; Balvis, T. Environmental Impact Assessment in Climbing Activities: A New Method to Develop a Sustainable Tourism in Geological and Nature Reserves. Geoheritage 2020, 12, 1-16. [CrossRef]

23. Rodríguez-Díaz, B.; Pulido-Fernández, J.I. Sustainability as a key factor in tourism competitiveness: A global analysis. Sustainability 2020, 12, 51. [CrossRef]

24. Dixon, J.A.; Fallon, L.A. The concept of sustainability: Origins, extensions, and usefulness for policy. Soc. Nat. Resour. 1989, 2, 73-84. [CrossRef]

25. Gao, L.; Bryan, B.A. Finding pathways to national-scale land-sector sustainability. Nature 2017, 544, 217-222. [CrossRef] [PubMed]

26. Luo, P.; Sun, Y.; Wang, S.; Wang, S.; Lyu, J.; Zhou, M.; Nakagami, K.; Takara, K.; Nover, D. Historical assessment and future sustainability challenges of Egyptian water resources management. J. Clean Prod. 2020, 263, 121154. [CrossRef]

27. Ek Styvén, M.; Mariani, M.M. Understanding the intention to buy secondhand clothing on sharing economy platforms: The influence of sustainability, distance from the consumption system, and economic motivations. Psychol. Mark. 2020, 37, 724-739. [CrossRef]

28. Peters, M.; Siller, L.; Matzler, K. The resource-based and the market-based approaches to cultural tourism in alpine destinations. J. Sustain. Tour. 2011, 19, 877-893. [CrossRef]

29. Zhou, Y.; Maumbe, K.; Deng, J.; Selin, S.W. Resource-based destination competitiveness evaluation using a hybrid analytic hierarchy process (AHP): The case study of West Virginia. Tour. Manag. Perspect. 2015, 15, 72-80. [CrossRef]

30. Denicolai, S.; Cioccarelli, G.; Zucchella, A. Resource-based local development and networked core-competencies for tourism excellence. Tour. Manag. 2010, 31, 260-266. [CrossRef]

31. Freeman, R.E. Strategic Management: A Stakeholder Approach; Cambridge University Press: Cambridge, UK, 1984.

32. Paunović, I.; Jovanović, V. Implementation of Sustainable Tourism in the German Alps: A Case Study. Sustainability 2017, 9, 226. [CrossRef]

33. Stylidis, D. Using Destination Image and Place Attachment to Explore Support for Tourism Development: The Case of Tourism Versus Non-tourism Employees in EILAT. J. Hosp. Tour. Res. 2020, 44, 951-973. [CrossRef]

34. Beritelli, P. Cooperation among prominent actors in a tourist destination. Ann. Tour. Res. 2011, 38, 607-629. [CrossRef]

35. Merinero-Rodríguez, R.; Pulido-Fernández, J.I. Analysing relationships in tourism: A review. Tour. Manag. 2016, 54, 122-135. [CrossRef]

36. Black, I.; Veloutsou, C. Working consumers: Co-creation of brand identity, consumer identity and brand community identity. J. Bus. Res. 2017, 70, 416-429. [CrossRef]

37. Fassin, Y.; de Colle, S.; Freeman, R.E. Intra-stakeholder alliances in plant-closing decisions: A stakeholder theory approach. Bus. Ethics A Eur. Rev. 2017, 26, 97-111. [CrossRef]

38. Su, L.; Swanson, S.R. The effect of destination social responsibility on tourist environmentally responsible behavior: Compared analysis of first-time and repeat tourists. Tour. Manag. 2017, 60, 308-321. [CrossRef]

39. Lüdeke-Freund, F.; Dembek, K. Sustainable business model research and practice: Emerging field or passing fancy? J. Clean. Prod. 2017, 168, 1668-1678. [CrossRef]

40. Schaltegger, S.; Hansen, E.G.; Lüdeke-Freund, F. Business Models for Sustainability: Origins, Present Research, and Future Avenues. Organ. Environ. 2016, 29, 3-10. [CrossRef]

41. Upward, A.; Jones, P. An Ontology for Strongly Sustainable Business Models: Defining an Enterprise Framework Compatible with Natural and Social Science. Organ. Environ. 2016, 29, 97-123. [CrossRef]

42. Ramkissoon, H. Perceived social impacts of tourism and quality-of-life: A new conceptual model. J. Sustain. Tour. 2020, 1-17. [CrossRef]

43. Chen, X.; Sun, X.; Yan, D.; Wen, D. Perceived sustainability and customer engagement in the online shopping environment: The rational and emotional perspectives. Sustainability 2020, 12, 2674. [CrossRef]

44. Taoketao, E.; Feng, T.; Song, Y.; Nie, Y. Does sustainability marketing strategy achieve payback profits? A signaling theory perspective. Corp. Soc. Responsib. Environ. Manag. 2018, 25, 1039-1049. [CrossRef]

45. Alon, A.; Vidovic, M. Sustainability performance and assurance: Influence on reputation. Corp. Reput. Rev. 2015, 18, 337-352. [CrossRef] 
46. Bae, S.M.; Masud, M.A.K.; Kim, J.D. A cross-country investigation of corporate governance and corporate sustainability disclosure: A signaling theory perspective. Sustainability 2018, 10, 2611. [CrossRef]

47. Michael Hall, C. Policy learning and policy failure in sustainable tourism governance: From first- and second-order to third-order change? J. Sustain. Tour. 2011, 19, 649-671. [CrossRef]

48. Kim, M.-S.; Thapa, B.; Kim, H. International Tourists' Perceived Sustainability of Jeju Island, South Korea. Sustainability 2017, 10, 73. [CrossRef]

49. Mbaiwa, J.E. Enclave tourism and its socio-economic impacts in the Okavango Delta, Botswana. Tour. Manag. 2005, 26, 157-172. [CrossRef]

50. Li, Q.; Wu, M. Tourists' pro-environmental behaviour in travel destinations: Benchmarking the power of social interaction and individual attitude. J. Sustain. Tour. 2020, 28, 1371-1389. [CrossRef]

51. Pike, S. Destination positioning opportunities using personal values: Elicited through the Repertory Test with Laddering Analysis. Tour. Manag 2012, 33, 100-107. [CrossRef]

52. Currie, S. Measuring and improving the image of a post-conflict nation: The impact of destination branding. J. Destin. Mark. Manag. 2020, 18, 100472 .

53. Kislali, H.; Kavaratzis, M.; Saren, M. Rethinking destination image formation. Int. J. Cult. Tour. Hosp. Res. 2016, 10, 70-80. [CrossRef]

54. Cassinger, C.; Eksell, J. The magic of place branding: Regional brand identity in transition. J. Place Manag. Dev. 2017, 10, 202-212 [CrossRef]

55. Campelo, A.; Aitken, R.; Thyne, M.; Gnoth, J. Sense of Place. J. Travel. Res. 2014, 53, 154-166. [CrossRef]

56. Hankinson, G. Relational network brands: Towards a conceptual model of place brands. J. Vacat. Mark. 2004, 10, 109-121. [CrossRef]

57. García, J.A.; Gómez, M.; Molina, A. A destination-branding model: An empirical analysis based on stakeholders. Tour. Manag. 2012, 33, 646-661. [CrossRef]

58. Kotsi, F.; Pike, S. Destination Brand Positioning Theme Development Based on Consumers' Personal Values. J. Hosp. Tour. Res. 2021, 45, 573-587. [CrossRef]

59. Deb, M. An empirical investigation on heritage destination positioning and loyalty. Curr. Issues Tour. 2020, 1-14. [CrossRef]

60. Warren, G.; Dinnie, K. Exploring the dimensions of place branding: An application of the ICON model to the branding of Toronto. Int. J. Tour. Cities 2017, 3, 56-68. [CrossRef]

61. Demirović Bajrami, D.; Radosavac, A.; Cimbaljević, M.; Tretiakova, T.N.; Syromiatnikova, Y.A. Determinants of Residents Support for Sustainable Tourism Development: Implications for Rural Communities. Sustainability 2020, 12, 9438. [CrossRef]

62. Barbieri, C.; Sotomayor, S.; Gil Arroyo, C. Sustainable Tourism Practices in Indigenous Communities: The Case of the Peruvian Andes. Tour. Plan Dev. 2020, 17, 207-224. [CrossRef]

63. Tranfield, D.; Denyer, D.; Smart, P. Towards a Methodology for Developing Evidence-Informed Management Knowledge by Means of Systematic Review. Br. J. Manag. 2003, 14, 207-222. [CrossRef]

64. Jiménez-García, M.; Ruiz-Chico, J.; Peña-Sánchez, A.R.; López-Sánchez, J.A. A bibliometric analysis of sports tourism and sustainability (2002-2019). Sustainability 2020, 12, 2840. [CrossRef]

65. Ji, Y.G.; Tao, W.; Rim, H. Mapping corporate social responsibility research in communication: A network and bibliometric analysis. Public Relat. Rev. 2020, 46, 101963. [CrossRef]

66. Vallaster, C.; Kraus, S.; Merigó Lindahl, J.M.; Nielsen, A. Ethics and entrepreneurship: A bibliometric study and literature review. J. Bus. Res. 2019, 99, 226-237. [CrossRef]

67. Fetscherin, M.; Guzman, F.; Veloutsou, C.; Cayolla, R.R. Latest research on brand relationships: Introduction to the special issue. J. Prod. Brand. Manag. 2019, 28, 133-139. [CrossRef]

68. Mulet-Forteza, C.; Martorell-Cunill, O.; Merigó, J.M.; Genovart-Balaguer, J.; Mauleon-Mendez, E. Twenty five years of the Journal of Travel \& Tourism Marketing: A bibliometric ranking. J. Travel. Tour. Mark. 2018, 35, 1201-1221. [CrossRef]

69. Carey, S.; Gountas, Y.; Gilbert, D. Tour operators and destination sustainability. Tour. Manag. 1997, 18, 425-431. [CrossRef]

70. Alejandria-Gonzalez, M.C.P. Cultural Tourism Development in the Philippines: An Analysis of Challenges and Orientations. J. Qual. Assur. Hosp. Tour. 2016, 17, 496-515. [CrossRef]

71. Sanchez-Fernandez, R.; Iniesta-Bonillo, M.-A.; Cervera-Taulet, A. Environmental Sustainability in the Mediterranean Destinations: A Latent Class Segmentation Analysis. Environ. Eng. Manag. J. 2018, 15, 1501-1510. [CrossRef]

72. Zhang, L.; Zhang, J. Perception of small tourism enterprises in Lao PDR regarding social sustainability under the influence of social network. Tour. Manag. 2018, 69, 109-120. [CrossRef]

73. Aydın, B.; Alvarez, M.D. Understanding the tourists' perspective of sustainability in cultural tourist destinations. Sustainability 2020, 12, 8846. [CrossRef]

74. Hennigs, N.; Schmidt, S.; Wiedmann, K.P.; Karampournioti, E.; Labenz, F. Measuring brand performance in the cruise industry: Brand experiences and sustainability orientation as basis for value creation. Int. J. Serv. Technol. Manag. 2017, 23, 189-203. [CrossRef]

75. Dioko, L. Progress and trends in destination branding and marketing-A brief and broad review. Tour. Hosp. Res. 2016, 34, 1-5. [CrossRef] 
76. Lee, S.W.; Xue, K. A model of destination loyalty: Integrating destination image and sustainable tourism. Asia Pacific J. Tour. Res. 2020, 25, 393-408. [CrossRef]

77. Vázquez-Martinez, U.J.; Sanchís-Pedregosa, C.; Leal-Rodríguez, A.L. Is gastronomy a relevant factor for sustainable tourism? An empirical analysis of Spain country brand. Sustainability 2019, 11, 2696. [CrossRef]

78. Ávila-Robinson, A.; Wakabayashi, N. Changes in the structures and directions of destination management and marketing research: A bibliometric mapping study, 2005-2016. J. Destin. Mark. Manag. 2018, 10, 101-111. [CrossRef]

79. Scott, M. A space tourism destination: Environmental, geopolitical and tourism branding considerations for New Zealand as a 'launch state'. J. Sustain. Tour. 2020, 1-14. [CrossRef]

80. Costa, J.; Rodrigues, D.; Gomes, J. Sustainability of tourism destinations and the importance of certification. Worldw. Hosp. Tour. Themes 2019, 11, 677-684. [CrossRef]

81. Coban, G.; Yildiz, O.S. Developing a destination management model: Case of Cappadocia. Tour. Manag. Perspect. 2019, 30, 117-128. [CrossRef]

82. Pulido-Fernández, J.I.; Andrades-Caldito, L.; Sánchez-Rivero, M. Is sustainable tourism an obstacle to the economic performance of the tourism industry? Evidence from an international empirical study. J. Sustain. Tour. 2015, 23, 47-64. [CrossRef]

83. Chin, C.H.; Chin, C.L.; Wong, W.P.M. The Implementation of Green Marketing Tools in Rural Tourism: The Readiness of Tourists? J. Hosp. Mark. Manag. 2018, 27, 261-280. [CrossRef]

84. Gertner, R.K. The impact of cultural appropriation on destination image, tourism, and hospitality. Thunderbird Int. Bus. Rev. 2019, 61, 873-877. [CrossRef]

85. Bigné, E.; Zanfardini, M.; Andreu, L. How online reviews of destination responsibility influence tourists' evaluations: An exploratory study of mountain tourism. J. Sustain. Tour. 2020, 28, 686-704. [CrossRef]

86. Dornier, R.; Mauri, C. Conclusions: Managing tourism sustainability in mountain destinations. Worldw. Hosp. Tour. Themes 2018, 10, 267-273. [CrossRef]

87. Quoquab, F.; Mohammad, J.; Mohd Sobri, A.M. Psychological engagement drives brand loyalty: Evidence from Malaysian ecotourism destinations. J. Prod. Brand. Manag. 2020, 30, 132-147. [CrossRef]

88. Campón-Cerro, A.M.; Hernández-Mogollón, J.M.; Alves, H. Sustainable improvement of competitiveness in rural tourism destinations: The quest for tourist loyalty in Spain. J. Destin. Mark. Manag. 2017, 6, 252-266. [CrossRef]

89. Guan, J.; Gao, J.; Zhang, C. Food heritagization and sustainable rural tourism destination: The case of China's Yuanjia Village. Sustainability 2019, 11, 2858. [CrossRef]

90. Lam-González, Y.E.; León, C.J.; de León, J. Coopetition in Maritime Tourism: Assessing the effect of Previous Islands' Choice and experience in tourist satisfaction. Sustainability 2019, 11, 6334. [CrossRef]

91. Tiago, T.; Faria, S.D.; Cogumbreiro, J.L.; Couto, J.P.; Tiago, F. Different shades of green on small islands. Isl. Stud. J. 2019, 11,601-618.

92. Kelman, I. Critiques of island sustainability in tourism. Tour. Geogr. 2019, 1-18. [CrossRef]

93. Moscardo, G.; Murphy, L. Using destination community wellbeing to assess tourist markets: A case study of Magnetic Island, Australia. J. Destin. Mark. Manag. 2016, 5, 55-64. [CrossRef]

94. D'Amato, D.; Korhonen, J.; Toppinen, A. Circular, Green, and Bio Economy: How Do Companies in Land-Use Intensive Sectors Align with Sustainability Concepts? Ecol. Econ. 2019, 158, 116-133. [CrossRef]

95. Salas-Zapata, W.A.; Ortiz-Muñoz, S.M. Analysis of meanings of the concept of sustainability. Sustain. Dev. 2019, $27,153-161$. [CrossRef]

96. Nikolaou, I.E.; Tsalis, T.A.; Evangelinos, K.I. A framework to measure corporate sustainability performance: A strong sustainability-based view of firm. Sustain. Prod. Consum. 2019, 18, 1-18. [CrossRef]

97. Bollani, L.; Bonadonna, A.; Peira, G. The Millennials' Concept of Sustainability in the Food Sector. Sustainability 2019, 11, 2984. [CrossRef]

98. Font, X.; McCabe, S. Sustainability and marketing in tourism: Its contexts, paradoxes, approaches, challenges and potential. J. Sustain. Tour. 2017, 25, 869-883. [CrossRef]

99. Toivonen, A. Sustainability dimensions in space tourism: The case of Finland. J. Sustain. Tour. 2020, 1-17. [CrossRef]

100. Chiu, Y.T.H.; Lee, W.I.; Chen, T.H. Environmentally responsible behavior in ecotourism: Antecedents and implications. Tour. Manag. 2014, 40, 321-329. [CrossRef]

101. Barnes, S.J.; Mattsson, J.; Sørensen, F.; Friis Jensen, J. The Mediating Effect of Experiential Value on Tourist Outcomes from Encounter-Based Experiences. J. Travel. Res. 2020, 59, 367-380. [CrossRef]

102. Wondirad, A.; Tolkach, D.; King, B. Stakeholder collaboration as a major factor for sustainable ecotourism development in developing countries. Tour. Manag. 2020, 78, 104024. [CrossRef] 